\title{
Estrogen-Responsive Genes Overlap with Triiodothyronine-Responsive Genes in a Breast Carcinoma Cell Line
}

\author{
Nancy Bueno Figueiredo, ${ }^{1}$ Sílvia Helena Cestari, ${ }^{1}$ Sandro José Conde, ${ }^{1}$ \\ Renata Azevedo Melo Luvizotto, ${ }^{1}$ Maria Teresa De Sibio, ${ }^{1}$ Denise Perone, ${ }^{1}$ \\ Maria Lúcia Hirata Katayama, ${ }^{2}$ Dirce Maria Carraro, ${ }^{3}$ Helena Paula Brentani, ${ }^{3}$ \\ Maria Mitzi Brentani, ${ }^{3}$ and Célia Regina Nogueira ${ }^{1,4}$ \\ ${ }^{1}$ Department of Internal Medicine, Botucatu School of Medicine, University of São Paulo State (UNESP), \\ 18618-000 Botucatu, SP, Brazil \\ ${ }^{2}$ Department of Radiology, Medicine School, University of São Paulo, USP, 01246-903 São Paulo, SP, Brazil \\ ${ }^{3}$ Research Center, AC Camargo Hospital, 01509-900 São Paulo, SP, Brazil \\ ${ }^{4}$ Department of Clinical Medicine of University of São Paulo State, Rubiao Junior District, s/n, 18618-000 Botucatu, SP, Brazil
}

Correspondence should be addressed to Célia Regina Nogueira; nogueira@fmb.unesp.br

Received 8 August 2013; Accepted 19 October 2013; Published 23 January 2014

Academic Editors: M. D. Galigniana and V. Sánchez-Margalet

Copyright (C) 2014 Nancy Bueno Figueiredo et al. This is an open access article distributed under the Creative Commons Attribution License, which permits unrestricted use, distribution, and reproduction in any medium, provided the original work is properly cited.

\begin{abstract}
It has been well established that estrogen plays an important role in the progression and treatment of breast cancer. However, the role of triiodothyronine $\left(\mathrm{T}_{3}\right)$ remains controversial. We have previously shown its capacity to stimulate the development of positive estrogen receptor breast carcinoma, induce the expression of genes (PR, TGF-alpha) normally stimulated by estradiol ( $\left.\mathrm{E}_{2}\right)$, and suppress genes (TGF-beta) normally inhibited by $\mathrm{E}_{2}$. Since $\mathrm{T}_{3}$ regulates growth hormones, metabolism, and differentiation, it is important to verify its action on other genes normally induced by $\mathrm{E}_{2}$. Therefore, we used DNA microarrays to compare gene expression patterns in MCF-7 breast adenocarcinoma cells treated with $\mathrm{E}_{2}$ and $\mathrm{T}_{3}$. Several genes were modulated by both $\mathrm{E}_{2}$ and $\mathrm{T}_{3}$ in MCF-7 cells (Student's $t$-test, $P<0.05$ ). Specifically, we found eight genes that were differentially expressed after treatment with both $\mathrm{E}_{2}$ and $\mathrm{T}_{3}$, including amphiregulin, fibulin 1, claudin 6, pericentriolar material 1, premature ovarian failure $1 B$, factor for adipocyte differentiation-104, sterile alpha motif domain containing 9, and likely ortholog of rat vacuole membrane protein 1 (fold change $>2.0, \mathrm{pFDR}<0.05$ ). We confirmed our microarray results by real-time PCR. Our findings reveal that certain genes in MCF-7 cells can be regulated by both $\mathrm{E}_{2}$ and $\mathrm{T}_{3}$.
\end{abstract}

\section{Introduction}

Most breast cancer risk factors are associated with prolonged exposure of the mammary gland to high levels of estrogen. The biological effects of estrogen are predominantly mediated by two estrogen receptors (ER) that bind to estrogen response elements (EREs) in the promoter region of target genes [1]. Although the involvement of thyroid hormones (TH) in the development and differentiation of normal breast tissue has been established [2-4] and epidemiological and experimental studies have associated $\mathrm{TH}$ pathologies with an increased risk of breast cancer, the role of $\mathrm{TH}$ remains controversial [5-14]. Vorherr [15] described an increase in the survival of hyperthyroid patients with breast cancer, whereas we have identified a biological link between breast cancer in postmenopausal women and subclinical hyperthyroidism [16]. Most, if not all, major triiodothyronine $\left(\mathrm{T}_{3}\right)$ actions are mediated by specific high affinity nuclear receptors (thyroid receptor, TR), which are encoded by the two genes THRA and THRB that are also ligand-regulated transcription factors that act via DNA response elements [17]. Recent results have revealed substantial changes in the expression profile of thyroid hormone receptors, suggesting that their deregulation may be involved in breast cancer development [18]. 
Thyroid receptor is present in both MCF-7 and MDAMB-231 breast cancer cell lines [19]. We previously demonstrated that $\mathrm{T}_{3}$ mimics the effects of estradiol $\left(\mathrm{E}_{2}\right)$ in the ER-positive breast cancer cell line MCF-7, stimulating growth, modulating mRNA transcription of growth factors, and inducing the expression and activity of $\mathrm{E}_{2}$-inducible proteins. In addition, these $\mathrm{T}_{3}$ effects were antagonized by the simultaneous addition of tamoxifen (TAM), which is a competitive inhibitor of $\mathrm{E}_{2}$ that binds to ER. However, we did not observe similar effects in the ER-negative MDA-MB-231 breast cancer cell line, in spite of high amounts of TR. This suggests that in MCF-7 cells both ligands share a common signaling pathway via ER, since the sequence similarity of these hormone receptors allows interactions of TR with EREs or ER with TREs [19]. These results are consistent with those of Zhou-Li et al. (1992), but contradictory to Dinda et al. [20, 21], who found no evidence that $T_{3}$ competitively displaces $E_{2}$ from ER. Recently, Hall et al. [22] showed that both $\mathrm{E}_{2}$ and $\mathrm{T}_{3}$ promoted proliferation in MCF-7 and T47 cell lines, which was suppressed by coadministration of the ER antagonist fulvestrant (ICI 182780), and $\mathrm{T}_{3}$ induced activation of EREmediated gene expression ( $\mathrm{ER} \alpha, \mathrm{ER} \beta$, and $\mathrm{PR}$ ) in MCF-7 cells. They also demonstrated that $\mathrm{T}_{3}$ enhanced the effect of $\mathrm{E}_{2}$ on cell proliferation in a dose-dependent manner.

We have demonstrated that tamoxifen inhibits transforming growth factor alpha (TGF $\alpha$ ) gene expression in human breast carcinoma samples treated in vitro with $\mathrm{T}_{3}$ [23]. These results suggest that $\mathrm{T}_{3}$ may play a role in breast cancer development and progression by regulating proliferation, gene expression, and activity of $\mathrm{E}_{2}$-inducible proteins such as progesterone receptor (PR) and TGF $\alpha$ and indicate an interaction between $\mathrm{E}_{2}$ and $\mathrm{T}_{3}$ signaling systems.

Here we systematically examined the transcriptional effects of $\mathrm{E}_{2}$ and $\mathrm{T}_{3}$ in the MCF-7 breast adenocarcinoma cell line using DNA microarrays in order to better understand the actions of these two hormones. We identified their effects on the expression of a large number of genes by using a microarray platform containing 4,608 open reading frame expressed sequence tags (Orestes) [24]. We demonstrated that the expression of eight genes was significantly altered by both $\mathrm{E}_{2}$ and $\mathrm{T}_{3}$ in MCF-7 cells (fold change $>2.0$, positive false discovery rate $(\mathrm{pFDR})<0.05)$. Out of these eight genes, amphiregulin (AREG), fibulin 1 (FBLN1), and claudin 6 (CLDN6) were the most differentially expressed.

\section{Materials and Methods}

2.1. Cell Line. MCF-7 cells were grown for 14 days before harvesting in RPMI 1640 supplemented with L-glutamine $(2.8 \mathrm{mM})$, insulin $(8 \mathrm{mIU} / \mathrm{mL})$, penicillin-streptomycin $(100 \mathrm{U} / \mathrm{mL})$, and $5 \%$ charcoal-stripped calf serum (FCS) and kept at $37^{\circ} \mathrm{C}$ in humidified $5 \% \mathrm{CO}_{2}$ and air. The medium was changed every two days.

2.2. Cell Treatment Conditions. MCF-7 cells were propagated in $150 \mathrm{~cm}^{3}$ culture flasks until they reached $40 \%$ confluence. Before starting hormone treatments, the medium was replaced with phenol red free RPMI 1640 to eliminate all known sources of estrogen [25]. After $24 \mathrm{~h}$ (day 0), the medium was changed and cells were treated in triplicate with $10^{-8} \mathrm{M} \mathrm{E}_{2}$ (Sigma-Aldrich, St. Louis, MO, USA, E8874), $10^{-8} \mathrm{M} \mathrm{T}_{3}$ (Sigma-Aldrich, T2752), and absolute ethanol (vehicle control) for $72 \mathrm{~h}$. Medium was changed every $24 \mathrm{~h}$. Cells were harvested at the times indicated and cell numbers were counted.

2.3. RNA Isolation and Reverse Transcription. Total RNA was extracted from cultured MCF-7 cells by the guanidinium thiocyanate method and analyzed by electrophoresis using $1 \%$ agarose gels. One microgram of total RNA was reversetranscribed with SuperScript III First-Strand Synthesis System for RT-PCR (Invitrogen, Carlsbad, CA, USA, 18080-051).

2.4. DNA Microarrays. The microarray glass slide was generated in conjunction with the Laboratório de Biologia Computacional (LBC_-Computational Biology Laboratory) at the Hospital do Câncer, São Paulo, Brazil, together with the Laboratório de Análise de Expressão Gênica (LGEA-Gene Expression Analysis Laboratory) at the Instituto Ludwig de Pesquisa sobre o Câncer, São Paulo. The slide contained 4,608 genes from the Human Cancer Genome Project Bank, Instituto Ludwig para a Pesquisa do Câncer, São Paulo. Microarray hybridization and analysis were performed as previously described [26].

2.5. Real-Time RT-PCR. Assay-on-Demand Gene Expression Product (Applied Biosystems, Foster City, CA, USA, 4331182), consisting of unlabeled PCR primers and a TaqMan MGB probe (FAM dye-labeled) optimized to work with the TaqMan Universal PCR Master Mix (P/N 4304437) in an ABI Prism 7700 system (Perkin Elmer Life Sciences, Boston, MA, USA), was employed to quantitatively measure $A R E G$, FBLN1, CLDN6, and glyceraldehyde-3-phosphate dehydrogenase $(G A P D H)$ mRNA expression. All assays were performed in triplicate. mRNA content was normalized to the GAPDH mRNA level and differences in expression were determined by the Ct method described in the ABI user's manual (Applied Biosystems).

2.6. Statistical Analysis. "Permutation" Student's $t$-test (10,000 permutations) was performed on microarray results without bootstrapping, with a positive false discovery rate (pFDR) less than 0.05, and fold change greater than 2.0.

\section{Results}

The influence of $\mathrm{T}_{3}$ on the gene expression profile of MCF-7 cells was examined and compared to the effects of treatment with $\mathrm{E}_{2}$. RNA samples extracted from triplicate samples of MCF-7 cells after $24 \mathrm{~h}$ of $\mathrm{E}_{2}$ or $\mathrm{T}_{3}$ treatment were analyzed for $\mathrm{E}_{2}$ - or $\mathrm{T}_{3}$-regulated gene expression by comparing to cells treated with vehicle control. Genes with $P<0.05$ (Student's $t$-test) in paired group comparisons were considered as differentially expressed. We verified that 393 genes were differentially expressed after both treatments (up- or downregulated) (Figure 1). After applying a 2-fold change 
TABLE 1: Genes significantly modulated by $\mathrm{E}_{2}$ and $\mathrm{T}_{3}$ in MCF-7 cells.

\begin{tabular}{|c|c|c|c|c|}
\hline \multirow[t]{2}{*}{ Symbol } & \multirow[t]{2}{*}{ Gene } & \multirow[t]{2}{*}{ Biological process } & \multicolumn{2}{|c|}{$\begin{array}{l}\text { Fold change } \\
\text { (adj. } P \text { value) }\end{array}$} \\
\hline & & & $\mathrm{E}_{2}$ & $\mathrm{~T}_{3}$ \\
\hline AREG & Amphiregulin, colorectum cell-derived, growth factor & Epidermal growth factor & 18.13 & 3.63 \\
\hline FAD104 & Fibronectin type III domain containing $3 \mathrm{~B}$ & Positive regulation of fat cell differentiation & 3.89 & 2.04 \\
\hline FBLN1 & Fibulin 1 & Interspecies interaction between organisms & 2.60 & 2.53 \\
\hline POF1B & Premature ovarian failure, $1 \mathrm{~B}$ & $\begin{array}{l}\text { Protein encoded by this gene binds nonmuscle actin } \\
\text { filaments }\end{array}$ & 2.58 & 2.34 \\
\hline CLDN6 & Claudin 6 & Calcium-independent cell-cell adhesion & 2.53 & 2.36 \\
\hline PCM1 & Pericentriolar material 1 & $\begin{array}{l}\text { G2/M transition of mitotic cell cycle/microtubule } \\
\text { anchoring }\end{array}$ & 2.38 & 2,02 \\
\hline FLJ20073 & Sterile alpha motif domain containing 9 & Regulation of cell proliferation and apoptosis & 2.22 & 2.46 \\
\hline$V M P 1$ & Likely ortholog of rat vacuole membrane protein 1 & Cell-cell adhesion & 2.41 & 2.11 \\
\hline
\end{tabular}

Fold: expression difference; $P$ value: significance value of Student's $t$-test; FDR: false discovery rate.

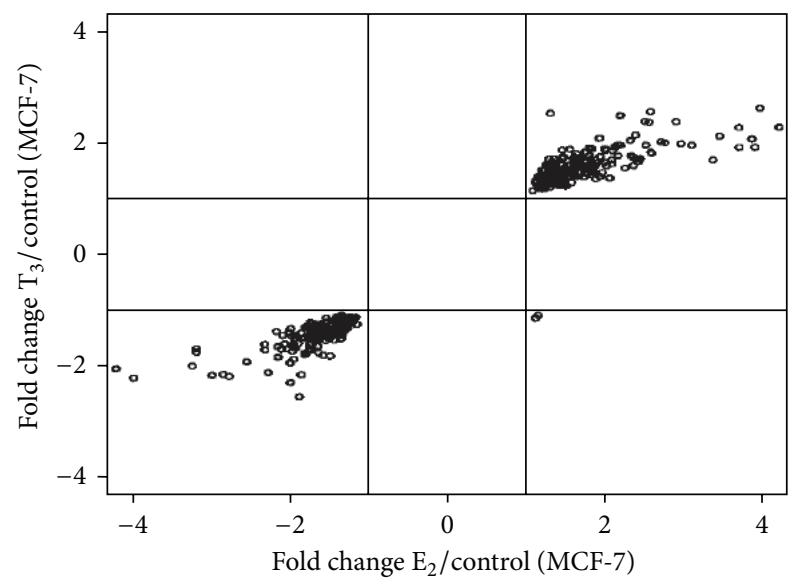

FIGURE 1: Dispersion of fold changes for the 393 genes modulated by $\mathrm{E}_{2}$ and $\mathrm{T}_{3}$ in MCF-7 cells. Each point represents the expression of one gene. The dispersion is similar in both treatments for all except two genes.

as a cut-off point and a pFDR $<0.05$, MCF-7 cells treated with $\mathrm{E}_{2}$ displayed 39 genes that were differentially expressed compared to the control, whereas after $\mathrm{T}_{3}$ treatment only 25 genes were differentially expressed relative to control cells. Eight genes were commonly modulated after treatment with both $\mathrm{E}_{2}$ and $\mathrm{T}_{3}$ (Table 1), although the response to $\mathrm{T}_{3}$ was less pronounced than to $\mathrm{E}_{2}$. Out of these eight genes, $A R E G$, $F B L N 1$, and CLDN6 were strongly expressed after treatment with both $\mathrm{T}_{3}$ and $\mathrm{E}_{2}$. In order to confirm our microarray data, we quantified $A R E G, F B L N 1$, and CLDN6 mRNAs using quantitative RT-PCR. Treatment with both $\mathrm{E}_{2}$ and $\mathrm{T}_{3}$ at $10^{-8} \mathrm{M}$ resulted in overexpression of AREG (26.3- and 13.8fold more, resp.), FBLN1 (5.3- and 1.9-fold more, resp.), and CLDN6 (4.4- and 2.2-fold more, resp.) (Figure 2).

\section{Discussion}

In breast cancer, several clinicopathological markers are frequently used alone or in combination to assess patient risk. For example, lymph-node stage, tumor size, and histologic grade are important elements of the major prognostic indices, whereas ER status is widely regarded as the primary predictor of response to hormonal (antiestrogen) therapy. Microarray data sets from large studies of breast carcinomas have revealed several underlying signatures associated with the primary physiology of the tumor that have important prognostic and predictive implications.

In previous studies, we have demonstrated that $T_{3}$, in supraphysiological doses, is able to increase the progression of ER-positive breast cancer, enhancing the expression of genes normally stimulated by $\mathrm{E}_{2}$ and suppressing genes normally inhibited by $\mathrm{E}_{2}$ [19]. Based on those results, we sought to identify genes that are influenced by both hormones in order to identify additional markers of progression.

Many genes were equally modulated by $\mathrm{E}_{2}$ and $\mathrm{T}_{3}$ in MCF-7 breast carcinoma cells (Student's $t$-test, $P<0.05$ ) (Figure 1). Using more stringent criteria (2-fold cutoff and pFDR $<0.05)$, the number of genes modified by $\mathrm{E}_{2}$ and $\mathrm{T}_{3}$ decreased to eight. Out of these eight genes, $A R E G, F B L N 1$, and CLDN6 were strongly expressed by both $\mathrm{T}_{3}$ and $\mathrm{E}_{2}$ treatment. We validated our microarray results using realtime PCR on AREG, FBLN1, and CLDN6 expression (Figure 2).

Amphiregulin (AREG), the most differentially expressed gene, codes for a glycoprotein, that is, a member of the epidermal growth factor family (EGF), the members of which are ligands that can bind EGFR. AREG was discovered in concentrated conditioned medium from MCF-7 cells [27]. Numerous studies have sought to characterize the transcriptional network associated with estrogen response using cell culture experiments. Kenney et al. [28] inserted pads with recombinant AREG in the breast of oophorectomized rats, which reestablished the premature development of the ductal mammary epithelium and prompted hyperplasia. Therefore, $A R E G$ seems to play an intermediary role in maturing the mammary gland and in stimulating the initiation of mammary oncogenesis. Martinez et al. [29] treated MCF7 cells with $10^{-9} \mathrm{M} \mathrm{E}_{2}, 10^{-9} \mathrm{M} \mathrm{E}_{2}$ with $10^{-6} \mathrm{M}$ TAM $\left(\mathrm{E}_{2}\right.$ + TAM), TAM alone, and vehicle control for 24 hours. 


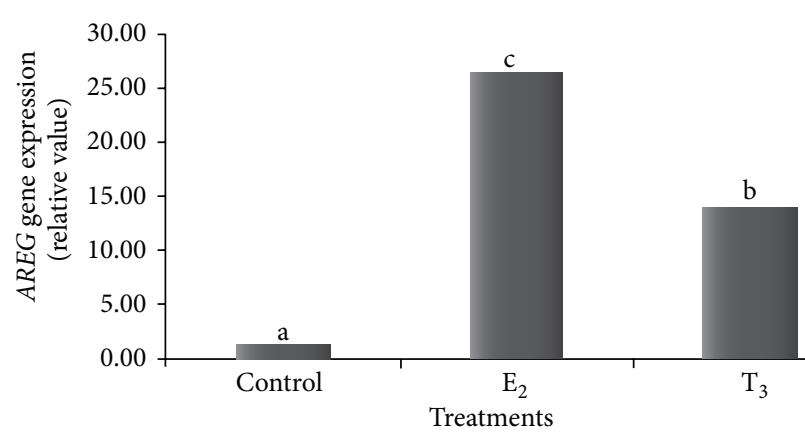

(a)

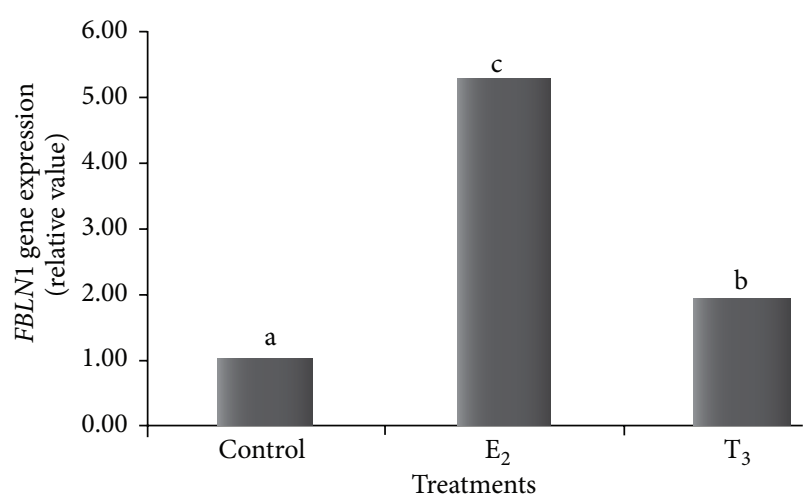

(b)

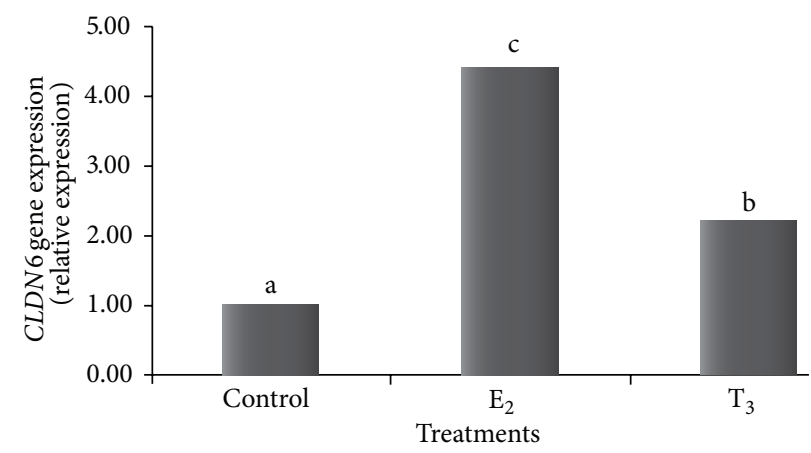

(c)

FIGURE 2: (a) Expression of AREG gene analyzed by real-time PCR in MCF-7 cells. (b) Expression of FBLN1 gene analyzed by real-time PCR in MCF-7 cells. (c) Expression of CLDN6 gene analyzed by real-time PCR in MCF-7 cells. Results are expressed relative to the expression in the control cells for $\mathrm{E}_{2}$-treated $\left(10^{-8} \mathrm{M}\right)$ and $\mathrm{T}_{3}$-treated $\left(10^{-8} \mathrm{M}\right) \mathrm{MCF}-7$ breast carcinoma cells. The use of different letters indicates that there was a statistical difference of $P<0.05$.

They observed that adding TAM to the treatment with $\mathrm{E}_{2}$ decreased AREG mRNA expression by $38 \%$, suggesting that $\mathrm{E}_{2}$ stimulates $A R E G$ expression via ER. Using microarrays, Frasor et al. [30] observed an upregulation of $A R E G$ in MCF7 cells treated with $\mathrm{E}_{2}$, which was reversed by tamoxifen. When Vendrell et al. [31] treated MVLN cells, a breast carcinoma cell line derived from MCF-7 cells, for 4 days with $\mathrm{E}_{2}$, they observed that $A R E G$ was one of the differentially expressed genes using cDNA miniarrays. A recent microarray analysis identified $\mathrm{E}_{2}$-regulated genes in a model in which human breast tissue was transplanted into mice, which were then treated with estradiol [32]. Interestingly, AREG was the most upregulated gene. Several studies have examined $A R E G$ expression in breast carcinomas by immunohistochemistry and found that $A R E G$ expression is higher in infiltrative breast carcinoma than in normal epithelium and is associated with regional lymph-node metastasis [33-35]. In addition, $A R E G$ upregulates the expression of genes associated with invasion [27]. Modulation of the AREG gene by $\mathrm{T}_{3}$ has not been previously reported. While the increase in $A R E G$ expression in MCF-7 cells after $\mathrm{T}_{3}$ treatment that we found was lower than the increase after $\mathrm{E}_{2}$ treatment, it was highly significant. Thus, AREG appears to be an important target gene for $\mathrm{E}_{2}$ and $\mathrm{T}_{3}$ in MCF-7 breast cancer cells.
Fibulin 1 (FBLN1) is the prototype member of the fibulin family of ECM proteins and binds to many ECM proteins, including fibronectin, laminin-1, fibrinogen, aggrecan, and versican. Fibulin 1 may be involved in cell motility and anchorage-independent growth of tumor cells [36] and is overexpressed in breast cancer specimens and breast cancer cell lines [37-39]. FBLN1 was previously reported to be induced by $\mathrm{E}_{2}$ in MCF-7 cells [40] and in ER-positive ovarian cancer cell lines [41]. We have shown for the first time that $F B L N 1$ is upregulated in breast cancer cell lines treated with $\mathrm{T}_{3}$.

Claudin 6 (CLDN6), a member of the Claudin family, is involved in the formation of the GAP junction [42]. While Offner et al. [43] reported the expression of CLDN6 in breast cancer cell lines, its role in carcinogenesis remains controversial [44-46]. Wu et al. [47] noted that cells with a high level of expression of claudin 6 grew slowly and had a higher rate of death than control cells, suggesting that claudin 6 may function as a cancer suppressor. Its downregulation may contribute to the malignant progression of certain types of breast cancers [48]. To our knowledge, this is the first study showing that $\mathrm{E}_{2}$ and $\mathrm{T}_{3}$ modulate CLDN6 expression in a breast cancer cell line.

Some of the other genes that we identified as being regulated by $\mathrm{E}_{2}$ and $\mathrm{T}_{3}$ are directly involved in cell proliferation, 
such as EMP1, IFNAR2, VMP, FLJ20073, MYC, and AREG, and some are involved in nucleotide binding and/or protein binding, such as PFKFB3, APPBP2, SSFA2, and NALP7. Other genes, such as CSTA, show altered expression in the tissue invasion process during breast carcinogenesis [49]. Expression of $B R A P$, responsible for ubiquitination of the product of the tumor suppressor gene $B R C A 1$, was increased in our study and in other studies [50] and FBLN1 and $A D A M 9$ are associated with migration and tissue invasion $[51,52]$. We also identified genes that had not been previously correlated with breast cancer, including TERF2IP, which is involved in telomere regulation [53], IGSF1, which is involved in intracellular adhesion and transcription and is a signal transduction regulator [54], NMT2, which acts in the protein myristoylation process [55], FAD104, which positively regulates fat cell differentiation [56], $P C M 1$, involved in centromere amplification and genomic instability [57], VWF, involved in cellular adhesion [58], $C 1 R$, which is involved in immune response and complement system activation [59], and $P O F 1 B$, which binds nonmuscle actin filaments [60].

This is the first report of $\mathrm{T}_{3}$ modulation of FBLN1, CLDN6, and AREG. The magnitude of the increase in expression of AREG, FBLN1, and CLDN6 in MCF-7 cells treated with $\mathrm{T}_{3}$ was less than when treated with $\mathrm{E}_{2}$ but highly significant. This may be because these genes have more binding consensus sequences for $\mathrm{E}_{2}$ than $\mathrm{T}_{3}$ receptors. Specifically, within $5,000 \mathrm{bp}$ upstream of the transcriptional initiation site, AREG has 10 EREs and 8 TREs, FBLN1 has 6 TREs and 6 EREs, and CLDN1 has 12 EREs and 10 TREs.

\section{Conclusion}

We have shown that $\mathrm{T}_{3}$ treatment results in a gene expression pattern similar to $\mathrm{E}_{2}$ treatment, up- or downregulating a group of the same genes, suggesting that these two hormones can cause similar phenotypes. Our in vitro observation suggests a molecular mechanism by which thyroid hormone can be a relevant factor for breast cancer progression through the induction of genes involved in growth and invasion.

\section{Conflict of Interests}

The authors declare that there is no conflict of interests regarding the publication of this paper.

\section{Acknowledgments}

The authors are grateful to the LIM-24 (FM-USP) and LGEA teams (Cancer Hospital) for their technical support. They also thank FAPESP for financial support (Grant no. 2002/09798-0). This paper has been proofread and edited by native English speakers with related background in BioMed proofreading.

\section{References}

[1] E. V. Jensen, G. Cheng, C. Palmieri et al., "Estrogen receptors and proliferation markers in primary and recurrent breast cancer," Proceedings of the National Academy of Sciences of the United States of America, vol. 98, no. 26, pp. 15197-15202, 2001.

[2] B. K. Vonderhaar and A. E. Greco, "Lobulo-alveolar development of mouse mammary glands is regulated by thyroid hormones," Endocrinology, vol. 104, no. 2, pp. 409-418, 1979.

[3] M. Lopez-Barahona, I. Fialka, J. M. Gonzalez-Sancho et al., "Thyroid hormone regulates stromelysin expression, protease secretion and the morphogenetic potential of normal polarized mammary epithelial cells," EMBO Journal, vol. 14, no. 6, pp. 1145-1155, 1995.

[4] J. M. Gonzalez-Sancho, A. Figueroa, M. Lopez-Barahona, E. Lopez, H. Beug, and A. Munoz, "Inhibition of proliferation and expression of T1 and cyclin D1 genes by thyroid hormone in mammary epithelial cells.," Molecular Carcinogenesis, vol. 34, pp. 25-34, 2002.

[5] T. Yokoe, Y. Iino, H. Takei et al., "Relationship between thyroidpituitary function and response to therapy in patients with recurrent breast cancer," Anticancer Research, vol. 16, no. 4, pp. 2069-2072, 1996.

[6] T. Yokoe, Y. Iino, H. Takei et al., "Changes of cytokines and thyroid function in patients with recurrent breast cancer," Anticancer Research, vol. 17, no. 1, pp. 695-699, 1997.

[7] M. B. Goldman, “Thyroid diseases and breast cancer," Epidemiologic Reviews, vol. 12, pp. 16-28, 1990.

[8] D. P. Rose and T. E. Davis, "Plasma thyroid-stimulating hormone and thyroxine concentrations in breast cancer," Cancer, vol. 41, no. 2, pp. 666-669, 1978.

[9] C. Giani, P. Fierabracci, R. Bonacci et al., "Relationship between breast cancer and thyroid disease: relevance of autoimmune thyroid disorders in breast malignancy," Journal of Clinical Endocrinology and Metabolism, vol. 81, no. 3, pp. 990-994, 1996.

[10] O. Takatani, T. Okumoto, H. Kosano, M. Nishida, H. Hiraide, and S. Tamakuma, "Relationship between the levels of serum thyroid hormones or estrogen status and the risk of breast cancer genesis in Japanese women," Cancer Research, vol. 49, no. 11, pp. 3109-3112, 1989.

[11] P. P. A. Smyth, D. F. Smith, E. W. M. McDermott, M. J. Murray, J. G. Geraghty, and N. J. O'Higgins, "A direct relationship between thyroid enlargement and breast cancer," Journal of Clinical Endocrinology and Metabolism, vol. 81, no. 3, pp. 937-941, 1996.

[12] J. Gogas, E. Kouskos, S. Tseleni-Balafouta et al., "Autoimmune thyroid disease in women with breast carcinoma," European Journal of Surgical Oncology, vol. 27, no. 7, pp. 626-630, 2001.

[13] O. Turken, Y. NarIn, S. DemIrbas et al., "Breast cancer in association with thyroid disorders," Breast Cancer Research, vol. 5, no. 5, pp. R110-R113, 2003.

[14] M. Cristofanilli, Y. Yamamura, S.-W. Kau et al., "Thyroid hormone and breast carcinoma: primary hypothyroidism is associated with a reduced incidence of primary breast carcinoma," Cancer, vol. 103, no. 6, pp. 1122-1128, 2005.

[15] H. Vorherr, "Thyroid function in benign and malignant breast disease," European Journal of Cancer and Clinical Oncology, vol. 23, no. 3, pp. 255-257, 1987.

[16] P. P. Saraiva, N. B. Figueiredo, C. R. Padovani, M. M. Brentani, and C. R. Nogueira, "Profile of thyroid hormones in breast cancer patients," Brazilian Journal of Medical and Biological Research, vol. 38, no. 5, pp. 761-765, 2005.

[17] J. M. González-Sancho, V. García, F. Bonilla, and A. Muñoz, "Thyroid hormone receptors/THR genes in human cancer," Cancer Letters, vol. 192, no. 2, pp. 121-132, 2003. 
[18] I. Conde, R. Paniagua, J. Zamora et al., "Influence of thyroid hormone receptors on breast cancer cell proliferation," Annals of Oncology, vol. 17, no. 1, pp. 60-64, 2006.

[19] C. R. Nogueira and M. M. Brentani, "Triiodothyronine mimics the effects of estrogen in breast cancer cell lines," Journal of Steroid Biochemistry and Molecular Biology, vol. 59, no. 3-4, pp. 271-279, 1996.

[20] F. Zhou-Li, V. Albaladejo, M. O. Joly-Pharaboz, B. Nicolas, and J. Andre, "Antiestrogens prevent the stimulatory effects of Ltriiodothyronine on cell proliferation," Endocrinology, vol. 130, no. 3, pp. 1145-1152, 1992.

[21] S. Dinda, A. Sanchez, and V. Moudgil, "Estrogen-like effects of thyroid hormone on the regulation of tumor suppressor proteins, p53 and retinoblastoma, in breast cancer cells," Oncogene, vol. 21, no. 5, pp. 761-768, 2002.

[22] L. C. Hall, E. P. Salazar, S. R. Kane, and N. Liu, "Effects of thyroid hormones on human breast cancer cell proliferation," Journal of Steroid Biochemistry and Molecular Biology, vol. 109, no. 1-2, pp. 57-66, 2008.

[23] S. J. Conde, R. A. M. Luvizotto, M. T. Sibio, M. L. H. Katayama, M. M. Brentani, and C. R. Nogueira, "Tamoxifen inhibits transforming growth factor- $\alpha$ gene expression in human breast carcinoma samples treated with triiodothyronine," Journal of Endocrinological Investigation, vol. 31, no. 12, pp. 1047-1051, 2008.

[24] R. R. Brentani, D. M. Carraro, S. Verjovski-Almeida et al., "Gene expression arrays in cancer research: methods and applications," Critical Reviews in Oncology/Hematology, vol. 54, no. 2, pp. 95105, 2005.

[25] Y. Berthois, N. Pourreau-Schneider, and P. Gandilhon, "Estradiol membrane binding sites on human breast cancer cell lines. Use of a fluorescent estradiol conjugate to demonstrate plasma membrane binding systems," Journal of Steroid Biochemistry, vol. 25, no. 6, pp. 963-972, 1986.

[26] M. A. A. Koike Folgueira, D. M. Carraro, D. F. da Costa Patrão et al., "Gene expression profile associated with response to doxorubicin-based therapy in breast cancer," Clinical Cancer Research, vol. 11, no. 20, pp. 7434-7443, 2005.

[27] N. E. Willmarth and S. P. Ethier, "Amphiregulin as a novel target for breast cancer therapy," Journal of Mammary Gland Biology and Neoplasia, vol. 13, no. 2, pp. 171-179, 2008.

[28] N. J. Kenney, G. H. Smith, I. G. Maroulakou et al., "Detection of amphiregulin and Cripto-1 in mammary tumors from transgenic mice," Molecular Carcinogenesis, vol. 15, pp. 44-56, 1996.

[29] L. Martinez, J. A. Castilla, T. Gil et al., "Thyroid hormones in fibrocystic breast disease," European Journal of Endocrinology, vol. 132, no. 6, pp. 673-676, 1995.

[30] J. Frasor, F. Stossi, J. M. Danes, B. Komm, C. R. Lyttle, and B. S. Katzenellenbogen, "Selective estrogen receptor modulators: discrimination of agonistic versus antagonistic activities by gene expression profiling in breast cancer cells," Cancer Research, vol. 64, no. 4, pp. 1522-1533, 2004.

[31] J. A. Vendrell, F. Magnino, E. Danis et al., "Estrogen regulation in human breast cancer cells of new downstream gene targets involved in estrogen metabolism, cell proliferation and cell transformation," Journal of Molecular Endocrinology, vol. 32, no. 2, pp. 397-414, 2004.

[32] C. J. Creighton, K. E. Cordero, J. M. Larios et al., "Genes regulated by estrogen in breast tumor cells in vitro are similarly regulated in vivo in tumor xenografts and human breast tumors," Genome Biology, vol. 7, no. 4, article R28, 2006.
[33] C.-F. Qi, D. S. Liscia, N. Normanno et al., "Expression of transforming growth factor $\alpha$, amphiregulin and cripto- 1 in human breast carcinomas," British Journal of Cancer, vol. 69, no. 5, pp. 903-910, 1994.

[34] L. Panico, D. 'Antonio A, G. Salvatore et al., "Differential immunohistochemical detection of transforming growth factor alpha, amphiregulin and CRIPTO in human normal and malignant breast tissues," International Journal of Cancer, vol. 65, no. 1, pp. 51-56, 1996.

[35] S. Desruisseau, J. Palmari, C. Giusti, S. Romain, P.-M. Martin, and Y. Berthois, "Clinical relevance of amphiregulin and VEGF in primary breast cancers," International Journal of Cancer, vol. 111, no. 5, pp. 733-740, 2004.

[36] W. S. Argraves, L. M. Greene, M. A. Cooley, and W. M. Gallagher, "Fibulins: physiological and disease perspectives," EMBO Reports, vol. 4, no. 12, pp. 1127-1131, 2003.

[37] L. M. Greene, W. O. Twal, M. J. Duffy et al., "Elevated expression and altered processing of fibulin-I protein in human breast cancer," British Journal of Cancer, vol. 88, no. 6, pp. 871-878, 2003.

[38] S. M. Pupa, W. S. Argraves, S. Forti et al., "Immunological and pathobiological roles of fibulin-1 in breast cancer," Oncogene, vol. 23, pp. 2153-2160, 2004.

[39] S. M. Pupa, S. Giuffré, F. Castiglioni et al., "Regulation of breast cancer response to chemotherapy by fibulin-1," Cancer Research, vol. 67, no. 9, pp. 4271-4277, 2007.

[40] A. Bardin, F. Moll, R. Margueron et al., "Transcriptional and posttranscriptional regulation of fibulin-1 by estrogens leads to differential induction of messenger ribonucleic acid variants in ovarian and breast cancer cells.," Endocrinology, vol. 146, pp. 760-768, 2005.

[41] G. M. Clinton, C. Rougeot, J. Derancourt et al., "Estrogens increase the expression of fibulin-1, an extracellular matrix protein secreted by human ovarian cancer cells," Proceedings of the National Academy of Sciences of the United States of America, vol. 93, no. 1, pp. 316-320, 1996.

[42] S. Tsukita and M. Furuse, "Occludin and claudins in tightjunction strands: leading or supporting players?” Trends in Cell Biology, vol. 9, no. 7, pp. 268-273, 1999.

[43] S. Offner, A. Hekele, U. Teichmann et al., "Epithelial tight junction proteins as potential antibody targets for pancarcinoma therapy," Cancer Immunology, Immunotherapy, vol. 54, no. 5, pp. 431-445, 2005.

[44] Y. Soini, "Claudins 2, 3, 4, and 5 in Paget's disease and breast carcinoma," Human Pathology, vol. 35, no. 12, pp. 1531-1536, 2004.

[45] Y. Soini, "Expression of claudins 1, 2, 3, 4, 5 and 7 in various types of tumours," Histopathology, vol. 46, no. 5, pp. 551-560, 2005.

[46] G. Sobel, C. Páska, I. Szabó, A. Kiss, A. Kádár, and Z. Schaff, "Increased expression of claudins in cervical squamous intraepithelial neoplasia and invasive carcinoma," Human Pathology, vol. 36, no. 2, pp. 162-169, 2005.

[47] Q. Wu, Y. Liu, Y. Ren et al., "Tight junction protein, claudin-6, downregulates the malignant phenotype of breast carcinoma," European Journal of Cancer Prevention, vol. 19, no. 3, pp. 186$194,2010$.

[48] C. Quan and S.-J. Lu, "Identification of genes preferentially expressed in mammary epithelial cells of Copenhagen rat using subtractive hybridization and microarrays," Carcinogenesis, vol. 24, no. 10, pp. 1593-1599, 2003. 
[49] I. Zajc, N. Sever, A. Bervar, and T. T. Lah, "Expression of cysteine peptidase cathepsin L and its inhibitors stefins A and B in relation to tumorigenicity of breast cancer cell lines," Cancer Letters, vol. 187, no. 1-2, pp. 185-190, 2002.

[50] T. Ueki, J.-H. Park, T. Nishidate et al., "Ubiquitination and downregulation of BRCA1 by ubiquitin-conjugating enzyme E2T overexpression in human breast cancer cells," Cancer Research, vol. 69, no. 22, pp. 8752-8760, 2009.

[51] C.-H. Yi, D. J. Smith, W. W. West, and M. A. Hollingsworth, "Loss of fibulin-2 expression is associated with breast cancer progression," American Journal of Pathology, vol. 170, no. 5, pp. 1535-1545, 2007.

[52] J. L. Fry and A. Toker, "Secreted and membrane-bound isoforms of protease ADAM9 have opposing effects on breast cancer cell migration," Cancer Research, vol. 70, no. 20, pp. 8187-8198, 2010.

[53] P. Martinez, M. Thanasoula, A. R. Carlos et al., "Mammalian Rap1 controls telomere function and gene expression through binding to telomeric and extratelomeric sites," Nature Cell Biology, vol. 12, no. 8, pp. 768-780, 2010.

[54] F. Xue, Y. Zhang, F. Liu, J. Jing, and M. Ma, "Expression of IgSF in salivary adenoid cystic carcinoma and its relationship with invasion and metastasis," Journal of Oral Pathology and Medicine, vol. 34, no. 5, pp. 295-297, 2005.

[55] V. Rioux, E. Beauchamp, F. Pedrono et al., "Identification and characterization of recombinant and native rat myristoylCoA: protein N-myristoyltransferases," Molecular and Cellular Biochemistry, vol. 286, no. 1-2, pp. 161-170, 2006.

[56] K. Kishimoto, X. Yuan, H. Auchincloss Jr., A. H. Sharpe, D. A. Mandelbrot, and M. H. Sayegh, "Mechanism of action of donor-specific transfusion in inducing tolerance: role of donor MHC molecules, donor co-stimulatory molecules, and indirect antigen presentation," Journal of the American Society of Nephrology, vol. 15, no. 9, pp. 2423-2428, 2004.

[57] A. Kodani, V. Tonthat, B. Wu, and C. Sütterlin, "Par6 $\alpha$ interacts with the dynactin subunit p150Gluedand is a critical regulator of centrosomal protein recruitment," Molecular Biology of the Cell, vol. 21, no. 19, pp. 3376-3385, 2010.

[58] J. E. Sadler, "von Willebrand factor assembly and secretion," Journal of Thrombosis and Haemostasis, vol. 7, no. 1, pp. 24-27, 2009.

[59] A. Láng, B. Major, K. Szilágyi et al., "Interaction between separated consecutive complement control modules of human Clr: implications for dimerization of the full-length protease," FEBS Letters, vol. 584, no. 22, pp. 4565-4569, 2010.

[60] A. Lacombe, H. Lee, L. Zahed et al., "Disruption of POF1B binding to nonmuscle actin filaments is associated with premature ovarian failure," American Journal of Human Genetics, vol. 79, no. 1, pp. 113-119, 2006. 


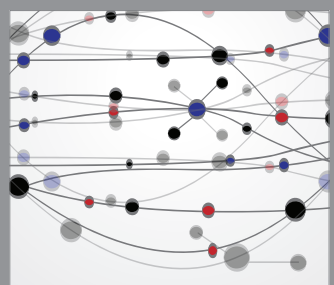

The Scientific World Journal
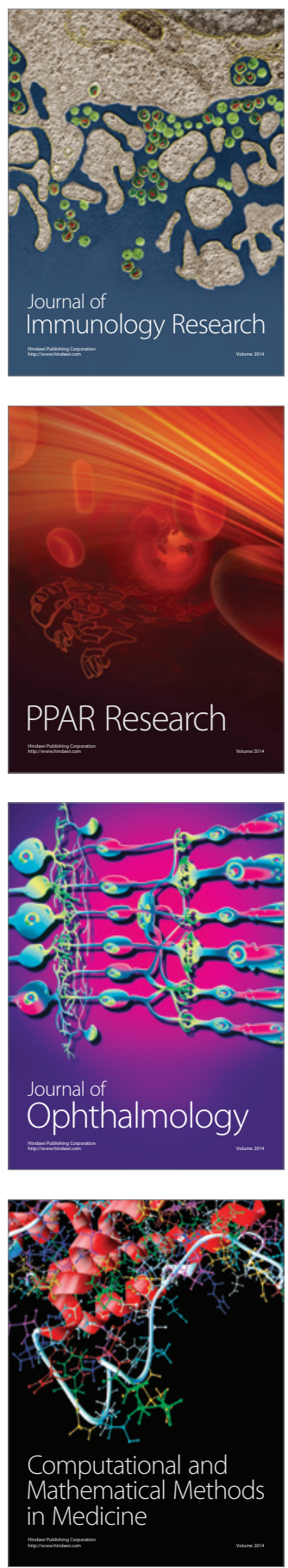

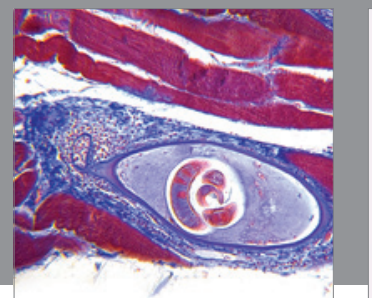

Gastroenterology

Research and Practice
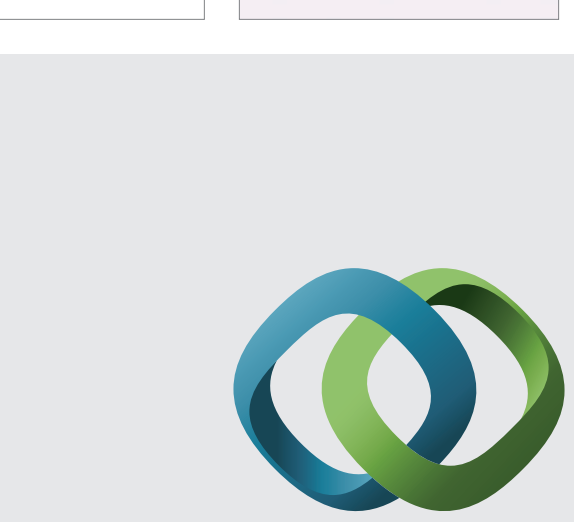

\section{Hindawi}

Submit your manuscripts at

http://www.hindawi.com
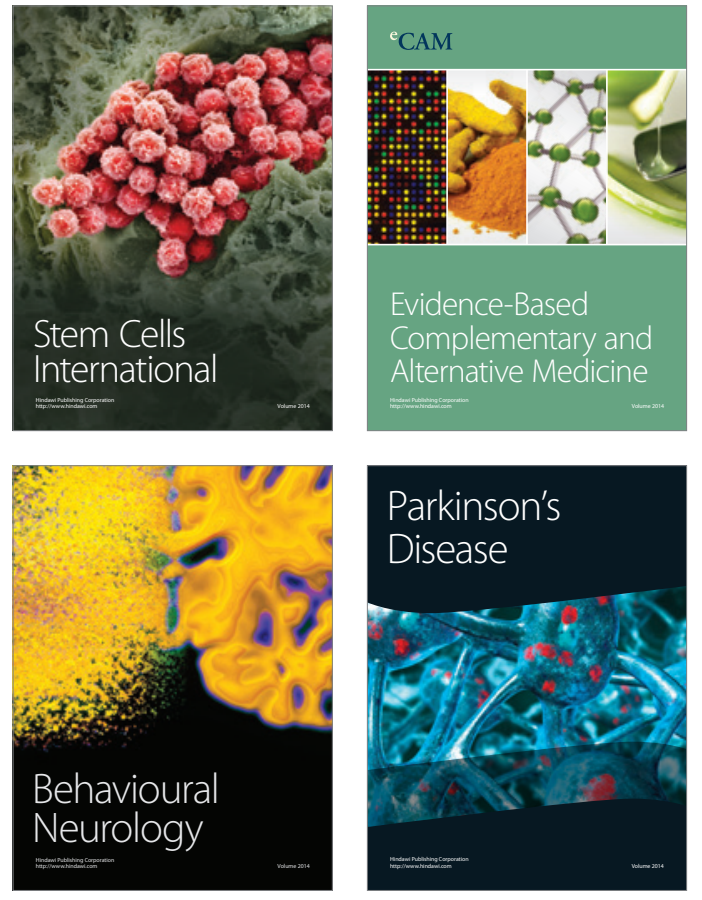
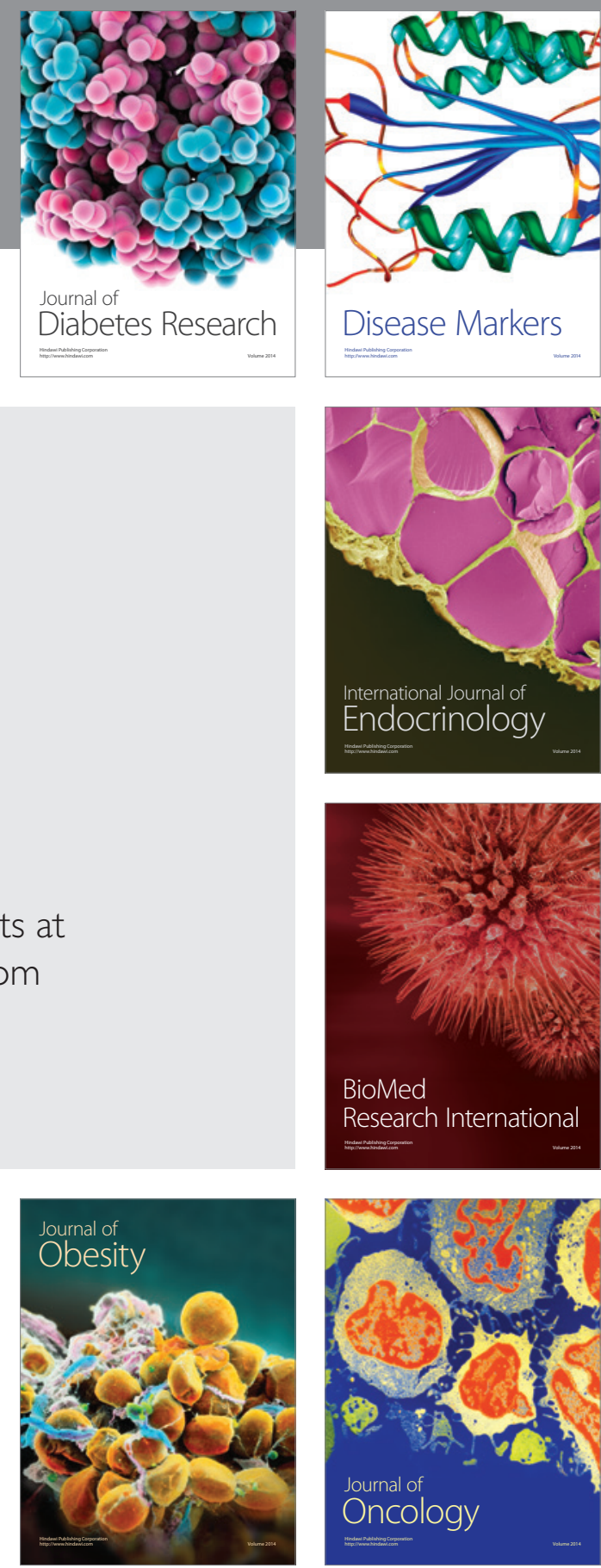

Disease Markers
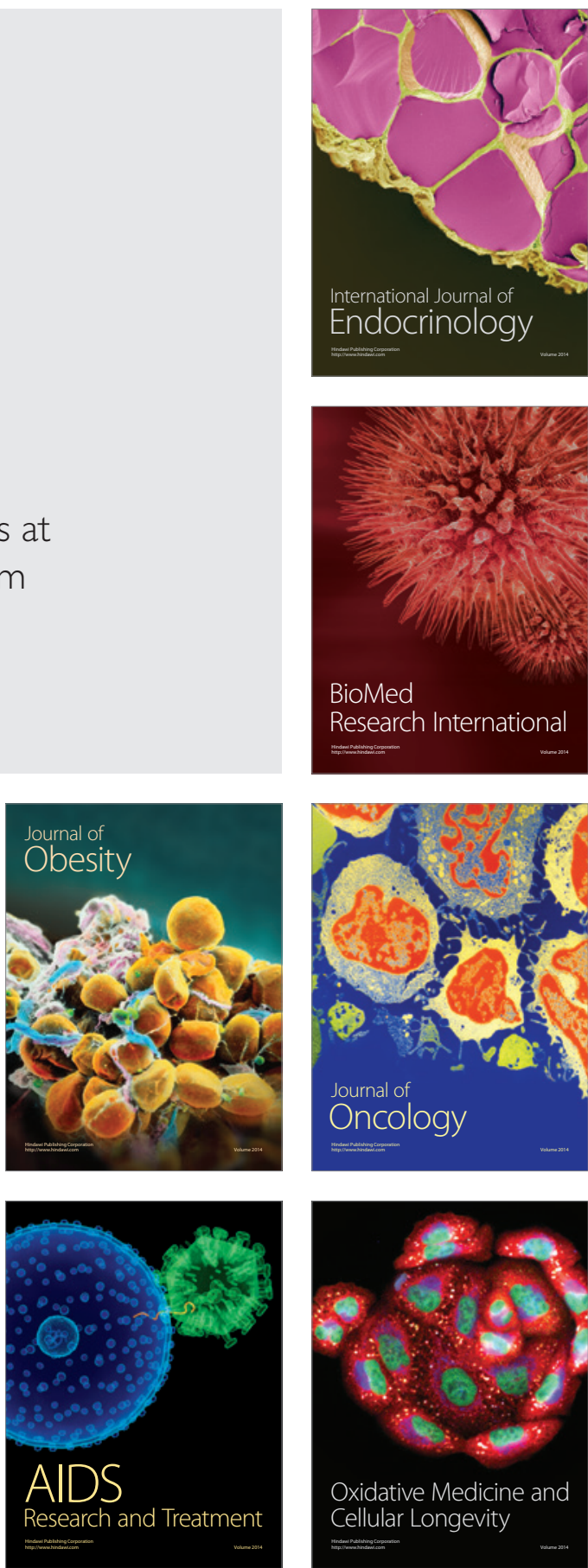